\title{
EVALUASI PENERAPAN GOOD CORPORATE GOVERNANCE PADA PT. BNI TBK KANTOR CABANG PEMBANTU UNSRAT
}

\author{
Jennifer Juliana Frans ${ }^{1}$, Herman Karamoy ${ }^{2}$, Victorina Z.Tirayoh ${ }^{3}$ \\ ${ }^{12}$ Fakultas Ekonomi dan Bisnis,Jurusan Akuntansi, Universitas Sam Ratulangi, Jl.Kampus Bahu, Manado, \\ 95115, Indonesia \\ E-mail : jenniferjulianafrans110795@gmail.com
}

\begin{abstract}
Implementation of Good Corporate Governance in the banking industry requires its own attention because the character of the banking industry is different from the industry in general. Good Corporate Governance is a bank governance that applies the principles of Transparency, Accountability, Responsibility, Independency, Fairness. The purpose of this study is to evaluate the application of the principles of Good Corporate Governance at PT. BNI Tbk kcp unsrat. The object of this research is PT BNI Tbk Kcp Unsrat. This research uses descriptive research design. The type of data used is qualitative data. Sources of data used are primary and secondary data. The research results show that with the implementation of the principles of Good Corporate Governance Bank BNI has applied the principle of openness well. The clarity of responsibility for the execution of functions and tasks is appropriate. Corporate responsibility is carried out in the presence of corporate social responsibility or CSR in the form of charitable activities. The Bank is managed independently in accordance with what has been implemented by BNI. Bank BNI Tbk has provided fair and equitable treatment.
\end{abstract}

Keywords : Transparancy, Accountability, Responsibility, Independence,

Fairness

\section{PENDAHULUAN}

1.1 Latar Belakang

Perkembangan saat ini yang cukup pesat dari industry perbankan dilihat sisi volume usaha, mobilisasi dana masyarakat, dan pemberian kredit. Setiap bank berlomba-lomba ingin mencari sumber pendanaannya, dengan keadaan seperti ini maka industry perbankan harus lebih inovatif dan kreatif dalam mengembangkan dan memperoleh sumber-sumber dana baru. Perekonomian di Indonesia dari tahun ke tahun mengalami pasang surut. Keadaan tersebut disebabkan karena adanya persaingan ketat di era globalisasi dan pasar bebas kancah internasional. Terbukti dengan adanya krisis ekonomi pada tahun 1997-1998 yang mengakibatkan perbankan di Indonesia mengalami keterpurukan yang sangat, banyak bankbank dilikuidasi karena tidak mampu mempertahankan kinerjanya. Salah satu penyebab terjadinya kebangkrutan bank tersebut, antara lain karena belum diterapkannya prinsipprinsip Good Corporate Governance (GCG) di lingkungan perbankan secara konsisten. Oleh karena itu berbagai upaya yang dilakukan oleh pemerintah termasuk Bank Indonesia dan Otoritas Jasa Keuangan (OJK) untuk mendorong terwujudnya Good Corporate Governance di lingkungan perbankan perlu kita dukung bersama. (Aprianingsih, 2016).

Bank Indonesia (BI) pada tanggal 30 januari 2006 yang lalu telah mengeluarkan Peraturan Bank Indonesia (PBI) No. 8/4/PBI/2006 tentang pelaksanaan Good Corporate Governance bagi Bank Umum. Tujuan dikeluarkan PBI tersebut adalah untuk memperkuat kondisi internal perbankan nasional dalam menghadapi risiko yang semakin kompleks, berupaya melindungi kepentingan para pemangku kepentingan (stakeholders), serta meningkatkan kepatuhan (compliance) terhadap peraturan perundang-undangan yang berlaku 
dan nilai-nilai etika yang berlaku umum pada industri perbankan. Dalam ketentuan ini, Good Corporate Governance merupakan suatu tata kelola bank yang menerapkan prinsip-prinsip Keterbukaan (transparency), Akuntabilitas (accountability), Pertanggungjawaban (responsibility), Independensi (independency), dan Kewajaran (fairness). (Effendi, 2016).

Good Corporate Governance merupakan serangkaian mekanisme yang merefleksikan suatu struktur pengelolaan perusahaan yang menetapkan distribusi hak dan tanggung jawab diantara berbagai partisipan di dalam perusahaan, termasuk para Pemegang Saham, Dewan Komisaris, Dewan Direksi, Manajer, Karyawan, dan pihak-pihak berkepentingan (stakeholders) lainnya (Darmawan, 2013).

Untuk mencapai keberhasilan harus memiliki formula yang baik dalam mengelola sumber daya yang dimiliki. Tata kelola perusahaan yang baik merupakan pedoman atau bisa digunakan sebagai formula untuk menciptakan pedoman bagi pengelola perusahaan dalam mengelola manajemen perusahaan yang baik dengan memperhatikan kepentingan stakeholders. Untuk mengurangi resiko dan ancaman yang dapat merugikan perusahaan, maka perlu diterapkannya tata kelola perusahaan yang baik. Oleh karena itu, perbankan harus menerapkan Good Corporate Governance untuk tata pengelolaan perbankan yang baik dan bisa melayani nasabah dengan baik pula. (Heriyanto, 2017). Mengingat pentingnya Tata Kelola Perusahaan yang baik khususnya di perbankan, maka penulis tertarik untuk melakukan penelitian dengan judul "Evaluasi Penerapan Good Corporate Governance Pada PT.BNI Tbk Kantor Cabang Pembantu Unsrat".

\subsection{Tujuan Penelitian}

Adapun tujuan yang ingin dicapai dalam penelitian ini yaitu untuk mengevaluasi penerapan Good Corporate Governance pada PT. BNI Tbk Kantor Cabang Pembantu Unsrat.

\section{TINJAUAN PUSTAKA}

\subsection{Akuntansi}

Akuntansi adalah suatu proses mencatat, mengklasifikasi, meringkas, mengolah dan menyajikan data, transaksi serta kejadian yang berhubungan dengan keuangan sehingga dapat digunakan oleh orang yang menggunakannya dengan mudah dimengerti untuk pengambilan suatu keputusan serta tujuan lainnya.

Akuntansi adalah sebuah sistem informasi yang dirancang oleh sebuah organisasi untuk mengidentifikasi (analisis, mencatat, dan meringkas) aktivitas-aktivitas yang mempengaruhi kondisi dan kinerja keuangannya kemudian mengkomunikasikan hasilnya kepada para pengambil keputusan, baik internal maupun eksternal organisasi (Pontoh, 2013:2)

\subsection{Akuntansi Manajemen}

Akuntansi Manajemen merupakan proses pengidentifikasian, pengukuran penghimpunan, penganalisaan, penyusunan, penafsiran dan pengkomunikasian informasi keuangan yang digunakan oleh manajemen untuk merencanakan, mengevaluasi dan mengendalikan kegiatan usaha di dalam sebuah organisasi, serta untuk memastikan penggunaandan akuntabilitas sumber daya yang tepat Henry Simamora (2012:13).

\subsection{Good Corporate Governance}

Pengertian Good Corporate Governance (GCG) adalah kumpulan hukum, peraturan, dan kaidah-kaidah yang wajib dipenuhi, yang dapat mendorong kinerja sumber-sumber perusahaan untuk berfungsi secara efisien gunna menghasilkan nilai ekonomi jangka panjang yang berkesinambungan bagi para pemegang saham maupun masyarakat sekitar secara keseluruhan (Turuis, 2017). Tata kelola perusahaan adalah salah satu kondisi yang dihadapi 
perusahaan-perusahaan public di Indonesia adalah masih terdapat kelemahan dalam menglola perusahaan. Sehingga sebagai salah satu upaya dalam mengatasi kelemahan tersebut, maka para pelaku bisnis menyepakati adanya penerapan Good Corporate Governance. (Febriani, 2016).

\subsection{Prinsip-Prinsip Good Corporate Governance}

a. $\quad$ Prinsip Transparency (transparansi)

Transparency (transparansi) mewajibkan adanya suatu informasi yang terbuka, tepat waktu, serta jelas, dan dapat diperbandingkan yang menyangkut keadaan keuangan, pengelolaan perusahaan, kinerja operasional, dan kepemilikan perusahaan.

\section{b. Prinsip Accountability (akuntabilitas)}

Accountability (akuntabilitas) dimaksudkan sebagai prinsip mengatur peran dan tanggung jawab manajemen agar dalam mengelola perusahaan dapat mempertanggungjawabkan serta mendukung usaha untuk menjamin penyeimbang kepentingan manajemen dan pemegang saham, sebagaimana yang diawasi oleh dewan komisaris.

\section{c. Prinsip Responsbility (responsibilitas)}

Responsbility (responsibilitas) perusahaan memastikan pengelolaan perusahaan dengan mematuhi peraturan perundang-undangan serta ketentuan yang berlaku sebagai cermin tanggung jawab korporasi sebagi warga korporasi yang baik.

\section{d. Prinsip Independency (indenpendensi)}

Independency (indenpendensi) perusahaan meyakini bahwa kemandirian merupakan keharusan agar organ perusahaan dapat bertugas dengan baik serta mampu membuat keputusan yang baik bagi perusahaan. Setiap organ perusahaan akan melaksanakan tugasnya sesuai dengan ketentuan perundang-undangan yang berlaku dan prinsip-prinsip GCG.

\section{e. Prinsip Fairness (kesetaraan/kewajaran)}

Kesetaraan mengandung makna bahwa terdapat perlakuan yang sama terhadap semua pemegang saham, termasuk investor asing dan pemegang saham minoritas, yaitu semua pemegang saham dengan kelas yang sama harus mendapat perlakuan yang sama pula

\subsection{Manfaat Good Corporate Governance}

Meningkatkan kinerja perusahaan melalui terciptanya proses pengambilan keputusan yang lebih baik, meningkatkan efisiensi operasional perusahaan, serta lebih meningkatkan pelayanan kepada stakeholder. Mempermudah diperolehnya dana pembiayaan yang lebih murah dan tidak rigid (karena faktor kepercayaan) yang pada akhirnya akan meningkatkan corporate value.

\subsection{Tujuan Good Corporate Governance}

Tujuan diterapkannya Good Corporate Governance menurut UU BUMN, yaitu Untuk memaksimalkan nilai BUMN dengan cara meningkatkan prinsip keterbukaan, akuntabilitas, dapat dipercaya, bertanggung jawab, dan adil agar perusahaan memiliki daya saing yang kuat, baik secara nasional maupun internasional .

Mendorong pengelolaan BUMN secara professional, transparan dan efisien, serta memberdayakan fungsi dan meningkatkan kemandirian organ. 


\section{METODE PENELITIAN}

\subsection{Jenis Penelitian}

Dalam penelitian ini digunakan jenis penelitian deskriptif dengan pendekatan kualitatif dengan cara peneliti secara langsung berinteraksi dengan objek penelitian. Penelitian kualitatif dalam Sugiyono (2016:1) adalah metode penelitian yang digunakan untuk meneliti pada kondisi objek yang alamiah, dimana penulis adalah instrument kunci, teknik pengumpulan data dilakukan secara triangulasi (gabungan), analisis data bersifat induktif dan hasil penelitian kualitatif lebih menekankan makna dari pada generalisasi.

\subsection{Tempat dan Waktu Penelitian}

Lokasi penelitian dilakukan di Manado provinsi sulut (Sulawesi Utara), tepatnya pada salah satu bank yaitu PT. Bank Negara Indonesia Tbk Kcp Unsrat, dengan alamat Kampus UNSRAT - Manado, Sulawesi Utara No.Telepon : (0431) 85146. Waktu penelitian dilaksanakan pada bulan Mei 2017 sampai selesai.

\subsection{Prosedur Penelitian}

1. Mengidentifikasi dan merumuskan masalah, menentukan objek penelitian yang sesuai dengan masalah.

2. Membuat rencana penelitian dengan membuat surat permohonan penelitian kepada PT. BNI Tbk Kantor Cabang Pembantu Unsrat

3. Mengumpulkan data-data yang relevan dengan cara wawancara, observasi dan dokumentasi.

4. Data yang telah dikumpulkan kemudian diolah, disajikan dan dianalisis, untuk mengetahui adanya penerapan Good Corporate Governance. Menarik kesimpulan dari hasil penelitian kemudian memberikan saran-saran kepada PT. BNI Tbk KCP Unsrat Manado berkaitan dengan penerapan Good Corporate Governance.

\subsection{Sumber Data}

Sumber data adalah segala sesuatu yang dapat memberikan informasi mengenai data. Adapun data yang saya peroleh melalui :

a. Data Primer

yaitu penelitian data secara langsung dengan mengadakan penelitian terhadap objek yang di teliti untuk memperoleh data primer, dan melakukan wawancara dengan

b. Data Sekunder

yaitu data yang diperoleh peneliti secara tidak lagsung melalui media perantara (Melihat penelitian yang sudah pernah dilakukan sebelumnya), menggunakan metode tinjauan kepustakaan (library research) membaca buku-buku yang berkaitan dengan masalah yang ingin diteliti, dan dilihat dari mengakses website dan situs-situs yang berkaitan.

\subsection{Metode analisis}

Analisis data yang digunakan pada penelitian ini adalah metode analisis data kualitatif. Analisis data dalam penelitian kualitatif, dilakukan pada saat pengumpulan data berlangsung. Pada saat wawancara, peneliti sudah melakukan analisis jawaban yang diwawancarai setelah dianalisis terasa belum memuaskan, maka penulis akan melanjutkan pertanyaan lagi, sampai tahap tertentu, diperoleh data yang dianggap kredibel. Dalam Sugiyono (2016:91) mengemukakan bahwa aktivitas dalam analisis data kualitatif dilakukan secara interaktif dan berlangsung secara terus menerus pada setiap tahapan penelitian sehingga sampai tuntas, dan datanya sampai jenuh. 


\section{HASIL ANALISIS DAN PEMBAHASAN}

\subsection{Hasil analisis}

\section{Penerapan Prinsip-Prinsip Good Corporate Governance di PT BNI Kcp Unsrat} Manado.

Berdasarkan hasil penelitian melalui wawancara dan dokumen yang diteliti, maka penulis memperoleh informasi tentang penerapan Good Corporate Governance yang diterapkan di PT. BNI Kcp Unsrat yaitu sebagai berikut :

\section{Penerapan Prinsip Transparansi}

Peraturan Bank Indonesia Nomor 8/4/PBI/2006 tanggal 30 Januari 2006 tentang Pelaksanaan Good Corporate Governance bagi Bank Umum. Saat ini, BNI adalah bank terbesar ke-4. BNI selalu berusaha untuk menjadi bank pilihan yang menyediakan layanan prima dan solusi bernilai tambah kepada seluruh nasabah di Indonesia berdasarkan total aset, total kredit maupun total dana pihak ketiga. Selain itu BNI berkewajiban untuk menyampaikan kepada masyarakat umum dan pemegang saham mengenai informasi perusahaan. Bank mengungkapkan informasi secara terbuka, baik dalam proses pengambilan keputusan maupun dalam mengungkapkan informasi material dan relevan mengenai perusahaan. PT BNI Kcp unsrat berkewajiban untuk melaporkan laporan keuangan bank ke pusat, hal ini bertujuan untuk menjamin transparansi keuangan bank yang ada. PT BNI Kcp unsrat selalu dipantau oleh BNI pusat dengan sistem online perbankan, sehingga jika terjadi penyelewengan keuangan bank bisa di ketahui oleh pusat. PT BNI Kcp unstr telah Go Public, laporan secara terbuka dan telah di publikasi dan dimana dengan peraturan GCG perusahaan yang telah go public wajib memberikan laporan kepada OJK. Dengan dibentuknya Sekertaris Perusahaaan yang berfungsi sebagai penghubung antara Perseroan dengan pemegang saham Perseroan, Otoritas Jasa Keuangan, dan pemangku kepentingan lainnya.penghubung bank dengan para investor, pelaku pasar modal, dan juga para pengamat dan membantu Direksi dan Dewan Komisaris dalam pelaksanaan tata kelola perusahaan yang meliputi:

a. Keterbukaan informasi kepada masyarakat, termasuk ketersediaan informasipada Situs Web Perseroan;

b. Penyampaian laporan kepada Otoritas Jasa Keuangan tepat waktu;

c. Penyelenggaraan dan dokumentasi Rapat Umum Pemegang Saham;

d. Penyelenggaraan dan dokumentasi rapat Direksi / Dewan Komisaris dan

e. Pelaksanaan program orientasi terhadap perusahaan bagi Direksi/ Dewan komisaris.

f. Pelaporan dan Pengungkapan Sekertaris Perusahaan.

\section{Penerapan Prinsip Akuntabilitas}

Agar pelaksanaan prisip akuntabilitas bisa maksimal, diperlukan kejelasan fungsi, dan pertanggungjawaban organ perusahaan yang mewajibkan semua keryawan melakukan aktivitasnya sesuai dengan job descriptionnya, sehingga pengelolaan terlaksana secara efektif. PT BNI kcp unsrat telah menerapkan mengenai adanya kejelasan tanggung jawab masing-masing organ organisasi yang selaras dengan visi, misi, sasaran usaha, dan strategi perusahaan. Tugas masing-masing organisasi telah dibuat dan dilaksanakan setiap tahunnya oleh setiap insan BNI sesuai dengan keputusan yang telah ditetapkan oleh perusahaan untuk mengatur Dewan Komisaris dalam melakukan perubahan dan tata tertib kerja dewan komisaris yang telah di tetapkan dalam surat Keputusan bersama Komisaris dan Direksi PT Bank Negara Indonesia (Persero) Tbk Nomor KEP/OO2IDK dan KP/244IDIR/R tanggal 29 Juni 2007 tentang Pedoman dan Tata Tertib Kerja Komisaris dan Direksi. 


\section{Penerapan Prinsip Responsibilitas}

Perusahaan selalu mengupayakan kemitraan dengan semua pemangku kepentingan dalam batas-batas peraturan perundang-undangan dan etika bisnis yang sehat. BNI Tbk telah sesuai dalam pengololaan perusahaan dan selalu mematuhi peraturan perundang-undangan yang berlaku. PT BNI Tbk Kcp unsrat selalu mematuhi peraturan perundang-undangan yang berlaku dan sesuai dengan prinsip GCG. Pertanggung jawaban perusahaan adalah perusahaan wajib membuat cara yang ditunjukan untuk melayani kepentingannya sendiri dan kepentingan stakeholders. PT BNI Kcp unsrat telah memenuhi kepatuhan bank dalam pelaksanaan prinsip kehati-hatian. PT BNI Kcp unsrat menerapkan fungsi kepatuhan yang sudah menjadi suatu keharusan bagi bisnis perbankan, Kepatuhan terhadap hukum, norma-norma dan aturan-aturan membantu memelihara reputasi bank, sehingga sesuai dengan harapan dari para nasabah, dan masyarakat secara keseluruhan.PT BNI Tbk Kcp unsrat telah melakukan tanggung jawab sosial perusahaan atau yang sering dikenal dengan CSR (Corporate Community Responsibility).

\section{Penerapan Prinsip Independensi}

Setiap organ perusahaan akan melaksanakan tugasnya sesuai dengan ketentuan perundang-undangan yang berlaku dan prinsip-prinsip GCG. Dalam rangka penerapan GCG PT BNI kcp unsrat berkewajiban untuk mematuhi Code Of Conduct (Kode Etik) yang dibuat oleh BNI. Sikap manajemen BNI dalam mengatasi ini sangat tegas karena BNI tidak melarang tapi kalau berminat masuk dibidang politik harus mengundurkan diri, jadi tidak bisa menjalankan bersama-sama berpolitik dan pegawai. Selain itu PT BNI Kcp unsrat memberikan informasi yang dimuat dalam Code Of Conduct tentang pegawai untuk menghindari empat Larangan Memberi, Menerima Hadiah atau Cinderamata. Semua insan PT BNI Kcp unsrat telah melaksanakan fungsi dan tugasnya dengan mengikuti peraturan perundang-undangan.

\section{Penerapan Prinsip Fairness}

Dalam pelaksanaan efektifitas fungsi audit ekstern maka PT BNI Kcp Unsrat telah memenuhi ketentuan mengenai hubungan antara Bank, Kantor Akuntan Publik dan BI sebagaimana diatur dalam ketentuan Bank Indonesia tentang Transparansi Kondisi Keuangan Bank. PT BNI Kcp unsrat menyampaikan laporan keuangan per 31 Desember setiap tahunnya yang telah diaudit kepada Bank Indonesia sesuai dengan ketentuan. BNI selalu melaksanakan Rapat Umum Pemegang Saham (RUPS) yang memungkinkan perlakuan yang sama terhadap semua pemegang saham, prosedur perusahaan tidak boleh mempersulit atau membutuhkan biaya mahal untuk menyampaikan suara. Setiap pemegang saham berhak mengeluarkan suara sesuai dengan klasifikasi dan jumlah saham yang dimiliki. Setiap pemegang saham berhak memperoleh informasi mengenai Perseroan, kecuali untuk informasi dimana Direksi memiliki alasan yang dapat dipertanggung jawabkan untuk tidak memberikannya.

\subsection{Pembahasan}

\section{A. Penerapan Prinsip Transparansi}

Dalam tata kelola perbankan nasional memerlukan sistem manajemen yang baik yang memberikan acuan dan motivasi kepada bank dalam mengelolah usaha perbankan, untuk itu bank harus ditangani secara profesional, transparan dan kehati-hatian agar supaya tidak akan terjadi bencana bagi perbankan. Bank Negara Indonesia adalah salah satu bank yang telah menerapkan, penerapan Good Corporate Governance, yang terkandum didalamnya penerapan prinsip Transparansi, dan berdasarkan pada hasil penelitian penerapan Transparansi, Bank Negara Indonesia Tbk Kcp Unsrat telah mengungkapkan informasi 
secara terbuka, baik dalam proses pengambilan keputusan maupun dalam mengungkapkan informasi material dan relevan mengenai perusahaan. Bank juga telah menyediakan informasi dengan jelas, memadai, dan tepat waktu.

\section{B. Penerapan Prinsip Akuntabilitas}

Berdasarkan hasil penelitian yang ada mengenai Akuntabilitas pada PT BNI Tbk Kcp unsrat, Akuntabilitas adalah kejelasan fungsi, struktur, system dan pertanggungjawaban elemen perusahaan. Apabila prinsip ini diterapkan secara efektif, maka akan ada kejelasan akan fungsi, hak, kewajiban dan wewenang serta tanggung jawab antara pemegang saham, dewan komisaris dan dewan direksi. Dewan direksi bertanggung jawab atas keberhasilan pengelolaan perusahaan dalam rangka mencapai tujuan yang telah ditetapkan oleh pemegang saham. Komisaris bertanggung jawab atas keberhasilan pengawasan dan wajib memberikan nasehat kepada direksi atas pengelolaan perusahaan sehingga tujuan perusahaan dapat tercapai. Tugas utama dari organisasi, melindungi kepentingan pemegang saham ataupun pihak lain yang berkepentingan dengan melakukan tinjauan klasifikasi atas integritas informasi dalam laporan keuangan, laporan operasional serta parameter yang digunakan untuk mengukur, melakukan klasifikasi dan penyajian dari laporan tersebut.

\section{Penerapan Prinsip Responsibilitas}

Bank adalah lembaga intermediasi dalam menjalankan kegiatan usahanya yang bergantung pada dana masyarakat dan kepercayaan baik dari dalam maupun luar negeri. Salah satu untuk menjalankan kegiatannya PT BNI Tbk Kcp unsrat telah menerapkan prinsip Responsibilitas yang artinya adalah kesesuaian atau kepatuhan didalam pengelolaan perusahaan terhadap prinsip korporasi yang sehat serta peraturan perundangan yang berlaku. Prinsip pertanggung jawaban PT BNI Tbk ditunjukkan oleh insan BNI dengan selalu mematuhi peraturan perundang-undangan yang berlaku sesuai dengan prisnip GCG.

\section{Penerapan Prinsip Independensi}

PT BNI Tbk Kcp unsrat dalam penerapan Prinsip independensi mewajibkan karyawan untuk tidak terikat dengan aktivitas politik sesuai yang telah diterapkan oleh BNI, kewajiban ini dibuat oleh bank BNI dalam Code Of Condutc tentang aktifitas politik dan untuk memenuhinya BNI tidak memperkenankan menerima pemberian dalam bentuk apapun agar tidak saling mendominasi. Jadi berdasarkan hasil penelitian yang ada bahwa PT BNI Tbk Kcp unsrat telah menerapkan prinsip independensi dengan baik.

\section{E. Penerapan Prinsip Fairness}

Dalam Prinsip kewajaran mengharuskan adanya perlakuan adil dan setara di dalam memenuhi hak-hak Pemegang Saham dan Stakeholders lainnya, baik yang timbul karena perjanjian maupun peraturan perundang-undangan yang berlaku serta kebijakan Perusahaan. Dalam penyajian informasi pada laporan keuangan PT BNI Tbk Kcp unsrat telah menyampaikan informasi laporan keuangan secara wajar tentang bagi hasil untuk para pemegang saham dan pemangku kepentingan dengan itu Bank telah memberikan pendapat yang independen atas kewajaran penyajian informasi pada laporan keuangan untuk kepentingan stakeholder.

\section{KESIMPULAN DAN SARAN}

\subsection{Kesimpulan}

1. Penerapan Prinsip Transparansi (Keterbukaan). Pada dasarnya Bank BNI telah menerapkan prinsip keterbukaan dengan baik. 
2. Accountability pada PT BNI Tbk Kcp Unsrat diwujudkan dengan kejelasan mengenai tanggung jawab atas pelaksanaan fungsi dan tugas-tugas sesuai wewenang yang dimiliki oleh seluruh organ perusahaan termasuk pemegang saham. PT BNI Tbk Kcp Unsrat, yang telah menerapkan mengenai adanya kejelasan tanggung jawab masingmasing organ organisasi

3. Tanggungjawaban perusahaan (kepatuhan) pada PT BNI Tbk Kcp Unsrat dilaksanakan dengan adanya tanggung jawab social perusahaan atau Corporate Social Responsibility ( CSR) berupa kegiatan amal.

4. Prinsip independensi ini mewajibkan karyawan untuk tidak terikat dengan aktivitas politik, sesuai yang telah diterapkan oleh BNI kewajiban ini dibuat oleh bank BNI dalam Code Of Condutc tentang aktifitas politik dan untuk memenuhinya BNI tidak memperkenankan menerima pemberian dalam bentuk apapun.

5. Bank telah menyampaikan informasi secara wajar tentang bagi hasil untuk para pemegang saham dan pemangku kepentingan. Bank telah memberikan perlakuan secara wajar dan setara untuk kepentingan stakeholder.

\subsection{Saran}

Berdasarkan kesimpulan dari hasil pembahasan di atas, maka penulis memberikan saran-saran kepada PT BNI Tbk Kcp Unsrat adalah sebagai berikut :

1. Kiranya BNI tetap mempertahankan prinsip Transparansi, agar supaya masyarakat secara umum bisa memperoleh informasi secara terbuka

2. Kiranya BNI Kcp Unsrat lebih meningkatkan program-program CSR agar supaya masyarakat secara umum bisa memperoleh informasi secara terbuka

3. Untuk kedepannya diharapkan BNI Tbk dapat terus mempertahankan dan meningkatkan sikap independensi tanpa adanya intervensi dari pihak manapun termasuk pemerintah, meskipun PT BNI Tbk termasuk BUMN

4. Pada prinsip Fairness PT BNI Tbk telah menerapkannya sebagai mana mestinya, jadi di harapkan PT BNI Tbk lebih meningkatkannya.

\section{DAFTAR PUSTAKA}

Aprianingsih Astri. 2016 “Pengaruh Penerapan Good Corporate Governance Struktur Kepemilikan, Dan Ukuran Perusahaan Terhadap Kinerja Keuangan Perbankan Yang Terdaftar Di Bursa Efek Indonesia Periode 2011-2014”. Program Studi Akuntansi Jurusan Pendidikan Akuntansi Fakultas Ekonomi Universitas Negeri Yogyakarta.

Efrizal Heriyanto. 2017. "Penerapan Prinsip Good Corporate Governance Dalam Aspek

Keterbukaan Di BNI Syariah Cabang Pangkalan Balai. Program Studi D3 Perbankan Syariah Fakultas Ekonomi Dan Bisnis Islam UIN Reden Fatah Palembang

Febriani, Al Musadieq, Afriyanti. 2016. "Pengaruh Good Corporate Governance Terhadap

Kinerja (Studi Pada Karyawan PT. Pos Indonesia (Persero) Tuban).’Jurnal

Administrasi Bisnis. Vol.32, No.1

Henry Simamora (2012:13) "Pengertian Akuntansi Manajemen"

https://manajemenakuntansi.wordpress.com/2012/.../pengertian-akuntansi-manajemen

Muh. Arief Effendi "The Power of Good Corporate Governance :Teori dan Implementasi

"Edisi 2, 2016, 2009 Penerbit Salemba Empat Jln.Raya Lenteng Agung No.101 Jagakarsa, Jakarta Selatan 
Rian Ikmal Darmawan. 2013. “Analisis Penerapan Good Corporate Governance Pada PT. Bank Negara Indonesia (Persero) Tbk”. Fakultas Ekonomi,Universitas Brawijaya.

Sugiyono, 2016. Memahami Penelitian Kualitatif. Bandung. Alfabeta Tahap-tahap penerapan Good corporate Governance https://faqiniez.wordpress.com/2010/11/15/gcg-goodcorporate-govermen/November 15,2010 @ 4:47 pm.

Tanri F. Turuis, 2017. Analisis Prosedur Pemberian Kredit Dengan Menggunakan PrinsipPrinsip Good Corporate Governanace Pada PT. Bank SulutGo. Jurusan Akuntansi, Fakultas Ekonomi dan Bisnis Universitas Sam Ratulangi Manado 95115. Indonesia Email :faiztanri@gmail.com

Pontoh, W. 2013. Akuntansi Konsep dan Aplikasi .Indeks. Jakarta. 